The Lands of Hawaii 



\section{The Lands of Hawaii}

\section{THEIR USE AND MISUSE}

Thomas H. Creighton

THE UNIVERSITY PRESS OF HAWAII I $^{\prime}$ Honolulu 
Copyright $(1978$ by The University Press of Hawaii

All rights reserved. No part of this work may be reproduced or transmitted in any form or by any means, electronic or mechanical, including photocopying and recording, or by any information storage or retrieval system, without permission in writing from the publisher.

Manufactured in the United States of America

\section{Library of Congress Cataloging in Publication Data}

Creighton, Thomas Hawk.

The lands of Hawaii.

Bibliography: $p$.

Includes index.

1. Land use-Hawaii-History. I. Title.

HD211.H3C73 333.7'09969 77-16124

ISBN 0-8248-0482-1 
For GWEN 
